\title{
p53, Bcl-2 and cox-2 are involved in berberine hydrochloride-induced apoptosis of HeLa229 cells
}

\author{
HAI-YAN WANG ${ }^{1}$, HAI-ZHONG YU ${ }^{1}$, SHENG-MOU HUANG ${ }^{1}$ and YU-LAN ZHENG ${ }^{2}$ \\ ${ }^{1}$ Department of Chemical Engineering and Food Science, Hubei University of Arts and Science, \\ Xiangyang, Hubei $441053 ;{ }^{2}$ Department of Respiratory Disease, Xiangyang Central Hospital, \\ Affiliated Hospital of Hubei University of Arts and Science, Xiangyang, Hubei 441021, P.R. China
}

Received October 6, 2015; Accepted July 21, 2016

DOI: $10.3892 / \mathrm{mmr} .2016 .5696$

\begin{abstract}
The present study aimed to investigate the effects of berberine hydrochloride on the proliferation and apoptosis of HeLa229 human cervical cancer cells. A 3-(4,5-dimethylthiazol-2-yl)-2,5-diphenyltetrazolium bromide assay was performed to examine the cytotoxicity of berberine hydrochloride against HeLa229 cells. The effects of berberine hydrochloride on the apoptosis of HeLa229 cells was detected by immunofluorescence and flow cytometry, and the mRNA expression levels of p53, B-cell lymphoma 2 (Bcl-2) and cyclooxygenase-2 (cox-2) were analyzed by reverse transcription-quantitative polymerase chain reaction. Berberine hydrochloride inhibited the proliferation of HeLa229 cells in a dose-dependent manner; minimum cell viability (3.61\%) was detected following treatment with $215.164 \mu \mathrm{mol} / \mathrm{l}$ berberine hydrochloride and the half maximal inhibitory concentration value was $42.93 \mu \mathrm{mol} / \mathrm{l}$ following treatment for $72 \mathrm{~h}$. In addition, berberine hydrochloride induced apoptosis in HeLa229 cells in a dose- and time-dependent manner. Berberine hydrochloride upregulated the mRNA expression levels of p53, and downregulated mRNA expression levels of Bcl-2 and cox-2, in a dose-dependent manner. In conclusion, berberine hydrochloride inhibited the proliferation and induced apoptosis of HeLa229 cells, potentially via the upregulation of p53 and the downregulation of Bcl-2 and cox-2 mRNA expression levels.
\end{abstract}

\section{Introduction}

Cervical cancer is one of the most prevalent female cancers (1), and is responsible for significant morbidity and mortality worldwide (2). A lack of effective treatment programs is a

Correspondence to: Professor Yu-Lan Zheng, Department of Respiratory Disease, Xiangyang Central Hospital, Affiliated Hospital of Hubei University of Arts and Science, 136 Jingzhou Street, Xiangyang, Hubei 441021, P.R. China

E-mail: xficuzyl@sina.com

Key words: berberine hydrochloride, HeLa229 human cervical cancer cells, cell proliferation, apoptosis, gene expression primary reason for this; therefore, novel therapeutic agents are required. Plants are being investigated for their use in chemotherapy, due to their availability, cost and lack of side-effects (3).

Berberine is an isoquinoline alkaloid derived from the Chinese herb Huang Lian (4), which is commonly used for the treatment of gastrointestinal complaints, diarrhea and other conditions. Previous studies have suggested that berberine exerts significant anticancer activities against various cancer cell types, including human breast cancer $(1,5)$, lung cancer (6), colon cancer (7), uterine leiomyoma (8), multiple myeloma (9), osteosarcoma $(10)$, prostate cancer $(11,12)$, cervical cancer $(13,14)$, nasopharyngeal carcinoma $(15,16)$, hepatocellular carcinoma (17-19), gastric carcinoma (20) and murine melanoma (21).

Berberine has been reported to suppress human papilloma virus (HPV) transcription and downstream signaling to induce growth arrest and apoptosis in SiHa and HPV18-positive cervical cancer cells via the modulation of activator protein 1 activity (22). In addition, berberine may reverse epithelial-to-mesenchymal transition, and inhibit metastasis and tumor-induced angiogenesis in SiHa cells (13). In Ca Ski human cervical cancer cells, berberine has been reported to enhance apoptosis via an increase in the ratio of p53 and B-cell lymphoma 2 (Bcl-2)-associated X protein (Bax)/Bcl-2, increased reactive oxygen species and calcium levels, disrupted mitochondrial membrane potential and increased caspase- 3 activity, as mediated by GADD153 (23). Although berberine has been demonstrated to possess anticancer activities, the underlying mechanisms by which it exerts these effects remain to be fully elucidated. In addition, the effects of berberine on HeLa229 cells have not been reported. Therefore, the present study aimed to investigate the effects of berberine hydrochloride on cell proliferation, apoptosis and associated gene expression in HeLa229 human cervical cancer cells.

\section{Materials and methods}

Materials. HeLa229 human cervical carcinoma cells were obtained from the China Center for Type Culture Collection (Wuhan, China). Berberine hydrochloride was purchased from Xi'an Guanyu Bio-Tech Co., Ltd. (Xi'an, China). Fetal calf serum (FCS) was purchased from Hangzhou Sijiqing 
Table I. Primer sequences for reverse transcription-quantitative polymerase chain reaction.

\begin{tabular}{|c|c|c|c|c|}
\hline \multirow[b]{2}{*}{ Gene } & \multicolumn{2}{|c|}{ Sequence $\left(5^{\prime}-3^{\prime}\right)$} & \multirow{2}{*}{$\begin{array}{l}\text { Product } \\
\text { size (bp) }\end{array}$} & \multirow[b]{2}{*}{ Reference } \\
\hline & Forward & Reverse & & \\
\hline$\beta$-actin & GTACCCTGGCATTGCCGACA & GGACTCGTCATACTCCTGCTTGCT & 181 & 26 \\
\hline p53 & GCCCACTTCACCGTACTAA & TGGTTTCAAGGCCAGATGT & 153 & 25 \\
\hline Bcl-2 & GGGAGGATTGTGGCCTTCTT & TCATCCACAGGGCGATGTT & 99 & 27 \\
\hline Cox-2 & CACCCATGTCAAAACCGAGG & CCGGTGTTGAGCAGTTTTCTC & 103 & 28 \\
\hline
\end{tabular}

Bcl-2, B-cell lymphoma 2; Cox-2, cyclooxygenase-2.

Biological Engineering Materials Co., Ltd. (Hangzhou, China). Trypsin and 3-(4,5-dimethylthiazol-2-yl)-2,5-diphenyltetrazolium bromide (MTT) were purchased from Amresco, LLC (Cleveland, OH, USA). Penicillin, streptomycin and dimethyl sulfoxide (DMSO) were obtained from Sigma-Aldrich; Merck Millipore (Darmstadt, Germany). The Annexin V-Fluorescein Isothiocyanate (FITC)/Propidium Iodide (PI) Apoptosis Detection kit was from BioVision, Inc. (Milpitas, CA, USA). All other chemicals and solvents used were of the highest purity grade available.

Cell culture and treatment. Cells were cultured in RPMI-1640 medium, supplemented with $10 \%$ heat-inactivated FCS, $100 \mathrm{IU} / \mathrm{ml}$ penicillin and $100 \mu \mathrm{g} / \mathrm{ml}$ streptomycin at $37^{\circ} \mathrm{C}$ in a humidified atmosphere containing $5 \% \mathrm{CO}_{2}$.

MTT assay. Cells in the exponential growth phase were harvested, adjusted to $2 \times 10^{4}$ cells $/ \mathrm{ml}$ and seeded in 96-well plates (200 $\mu \mathrm{l} /$ well). Following a $24-\mathrm{h}$ incubation at $37^{\circ} \mathrm{C}$, the medium was removed and berberine hydrochloride was added to wells in a final concentration range of 3.362-215.168 $\mu \mathrm{mol} / 1$. The plate was incubated for a further $72 \mathrm{~h}$, following which $20 \mu 15 \mathrm{mg} / \mathrm{ml}$ MTT reagent was added to wells. Subsequent to a 4-h incubation at $37^{\circ} \mathrm{C}$, formazan crystals formed by live cells were dissolved with $150 \mu \mathrm{l}$ DMSO and absorbance was measured at $490 \mathrm{~nm}$ using a microplate reader (DG5033A; Nanjing Huadong Electronics Group Medical Equipment Co., Ltd., Nanjing, China). Viability was determined using the following formula: $\%$ of growth = (optical density of treated cells/optical density of untreated cells) $\mathrm{x} 100$. The half maximal inhibitory concentration $\left(\mathrm{IC}_{50}\right)$ values were calculated as the concentration of drug required to inhibit $50 \%$ proliferation compared with untreated cells.

Detection of apoptosis-microscopy. Experiments were conducted as described previously $(24,25)$, using an Annexin V-FITC/PI Apoptosis Detection kit. Cells at a density of $1.5 \times 10^{5}$ cells $/ \mathrm{ml}$ were incubated with 26.896 or $107.584 \mu \mathrm{mol} / 1$ berberine hydrochloride at $37^{\circ} \mathrm{C}$ for $48 \mathrm{~h}$. Adherent and floating cells were harvested, washed twice with PBS and suspended in $500 \mu \mathrm{l}$ of $1 \mathrm{X}$ Binding Buffer. Annexin V-FITC (5 $\mu \mathrm{l})$ and $10 \mu \mathrm{l}$ PI were added and cells were vortexed and incubated for $5 \mathrm{~min}$ in the dark. Cells were visualized immediately using an inverted fluorescence biological microscope XD-101 (Nanjing Jiangnan Photovoltaic Group Co., Ltd., Nanjing, China).
Detection of apoptosis-flow cytometry. Cells at a density of $1.5 \times 10^{5}$ cells $/ \mathrm{ml}$ were incubated with 42.93 or $107.584 \mu \mathrm{mol} / 1$ berberine hydrochloride at $37^{\circ} \mathrm{C}$ for 24,48 and $72 \mathrm{~h}$. Apoptosis was detected using the Annexin V-FITC/PI Apoptosis Detection kit, as aforementioned. Cells were analyzed immediately by flow cytometry using an FC 500 (Beckman Coulter, Inc., Brea, CA, USA).

Reverse transcription-quantitative polymerase chain reaction $(R T-q P C R)$. Cells $\left(1.5 \times 10^{5}\right.$ cells $\left./ \mathrm{ml}\right)$ were incubated with 21.465 , 42.93 or $107.584 \mu \mathrm{mol} / 1$ berberine hydrochloride for $48 \mathrm{~h}$. Total RNA was prepared using TRIzol ${ }^{\circledR}$ reagent (Invitrogen; Thermo Fisher Scientific, Inc., Waltham, MA, USA) according to the manufacturer's protocol and was reverse transcribed using RevertAid ${ }^{\mathrm{TM}}$ Moloney Murine Leukemia Virus Reverse Transcriptase and oligo (dT) primers (Fermentas; Thermo Fisher Scientific, Inc., Pittsburgh, PA, USA). qPCR was performed on the resulting cDNA using an ABI 7900HT Fast Real Time PCR system (Applied Biosystems; Thermo Fisher Scientific, Inc.) and SYBR ${ }^{\circledR}$ Green Real Time PCR Master mix (Toyobo Co., Ltd., Osaka, Japan). The reaction mixture volume was $25 \mu \mathrm{l}$, including 11.2 $\mu \mathrm{l}$ PCR water, $2.5 \mu \mathrm{l} \mathrm{SYBR}{ }^{\circledR}$ Green Real Time PCR Master mix, $0.5 \mu \mathrm{l}$ forward primer $(10 \mu \mathrm{M}), 0.5 \mu \mathrm{l}$ reverse primer $(10 \mu \mathrm{M})$ and $0.3 \mu \mathrm{l} \mathrm{cDNA}$. Primers were synthesized by Shanghai Generay Biotech Co., Ltd. (Shanghai, China), and sequences are presented in Table I. The cycling conditions were as follows: An initial denaturation step at $94^{\circ} \mathrm{C}$ for $7 \mathrm{~min}$, followed by 35 cycles of denaturation at $94^{\circ} \mathrm{C}$ for $30 \mathrm{sec}$, annealing at $63^{\circ} \mathrm{C}$ for $30 \mathrm{sec}$ and extension at $72^{\circ} \mathrm{C}$ for $20 \mathrm{sec}$. Results were analyzed to determine the PCR cycle number that generated the first fluorescence signal over a threshold [quantification cycle $(\mathrm{Cq}), 10$ standard deviations (SDs) over the mean fluorescence generated during the baseline cycles], following which the $\Delta \Delta \mathrm{Cq}$ method was used to measure relative gene expression (29). Expression of the analyzed genes were normalized to the endogenous reference gene, $\beta$-actin.

Statistical analysis. All experiments were performed in triplicate. Data are expressed as the mean \pm SD. Data were analyzed in SPSS version 16.0 (SPSS, Inc., Chicago, IL, USA), using one-way analysis of variance followed by the least significant difference test to compare treatment and control groups. $\mathrm{P}<0.05$ was considered to indicate a statistically significant difference. 


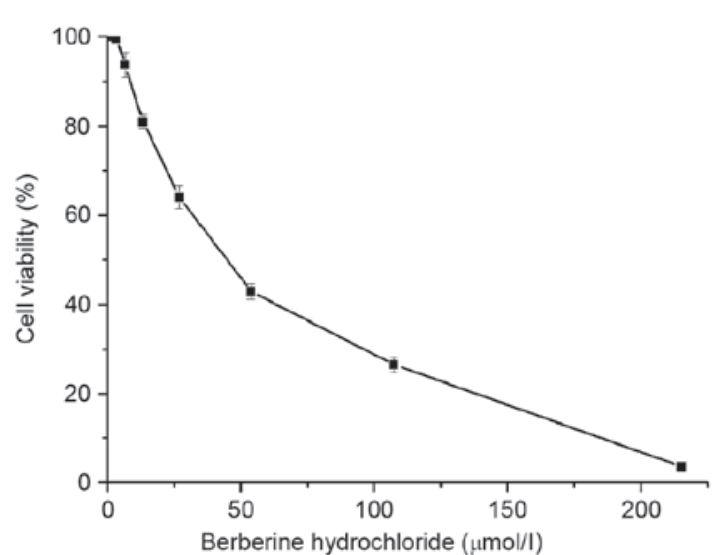

Figure 1. Cell viability of HeLa229 cells following incubation with various concentrations of berberine hydrochloride for $72 \mathrm{~h}$. Berberine hydrochloride decreased HeLa229 cell viability in a dose-dependent manner. Data are presented as the mean \pm standard deviation of three individual experiments.

\section{Results}

Berberine hydrochloride reduces cell viability. The effects of berberine hydrochloride on the viability of HeLa229 human cervical carcinoma cells were evaluated using an MTT assay (Fig. 1). The $\mathrm{IC}_{50}$ for HeLa229 cells at $72 \mathrm{~h}$ was $42.93 \mu \mathrm{mol} / 1$. Berberine hydrochloride inhibited HeLa229 cells in a dose-dependent manner. Cell viability following treatment with $3.362,6.724,53.791$ and $215.164 \mu \mathrm{mol} / 1$ berberine hydrochloride treatment was 99.56, 93.61, 42.85 and $3.61 \%$, respectively. The results demonstrated that HeLa229 cell viability was reduced following a 72-h incubation with berberine hydrochloride.

Berberine hydrochloride induces apoptosis of HeLa229 cells. Apoptosis of HeLa229 cells was detected using the Annexin V-FITC/Propidium Iodide Apoptosis Detection kit. As presented in Fig. 2, apoptotic cells could be observed clearly by fluorescence microscopy. The cell membranes of early and late apoptotic cells were FITC-positive (green), whereas late apoptotic cells additionally had PI-positive (red) nuclei accompanied by condensed chromatin and apoptotic bodies. Increased numbers of late apoptotic cells were observed following treatment with $107.584 \mu \mathrm{mol} / 1$, compared with $26.896 \mu \mathrm{mol} / \mathrm{l}$ berberine hydrochloride.

As presented in Fig. 3, no significant differences were observed in the proportions of early apoptotic cells following treatment with 42.93 or $107.584 \mu \mathrm{mol} / \mathrm{l}$ berberine hydrochloride for 24 or $48 \mathrm{~h}$, compared with untreated control cells; or in the proportions of late apoptotic cells following treatment with $42.93 \mu \mathrm{mol} / 1$ berberine hydrochloride for $24 \mathrm{~h}$, compared with control cells. Significant early apoptosis was observed following treatment with 42.93 or $107.584 \mu \mathrm{mol} / 1$ berberine hydrochloride for $72 \mathrm{~h}$, at 2.37 and $8.37 \%$ of cells, respectively (all $\mathrm{P}<0.001)$. The percentage of late apoptotic cells treated with $42.93 \mu \mathrm{mol} / 1$ berberine hydrochloride for $48 \mathrm{~h}$ was greater than for cells treated with $107.584 \mu \mathrm{mol} / 1$ berberine hydrochloride; however, this was reversed at $72 \mathrm{~h}$, at 16.43 and $37 \%$, respectively. The percentage of total apoptotic cells increased markedly from $7.3 \%$ in the $42.93 \mu$ mol/l treatment
A

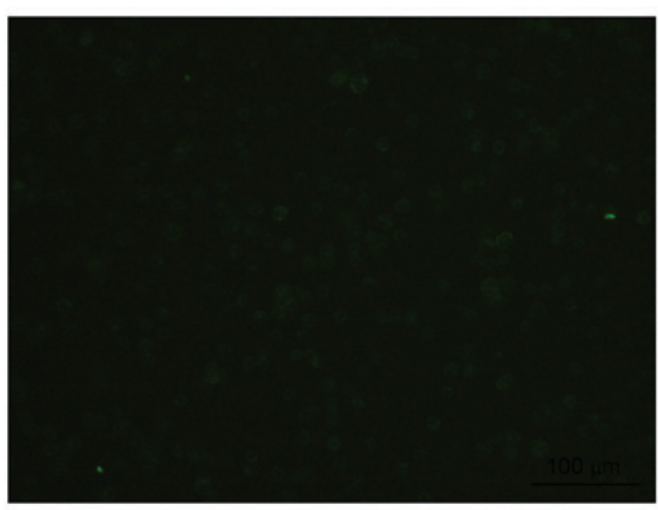

B

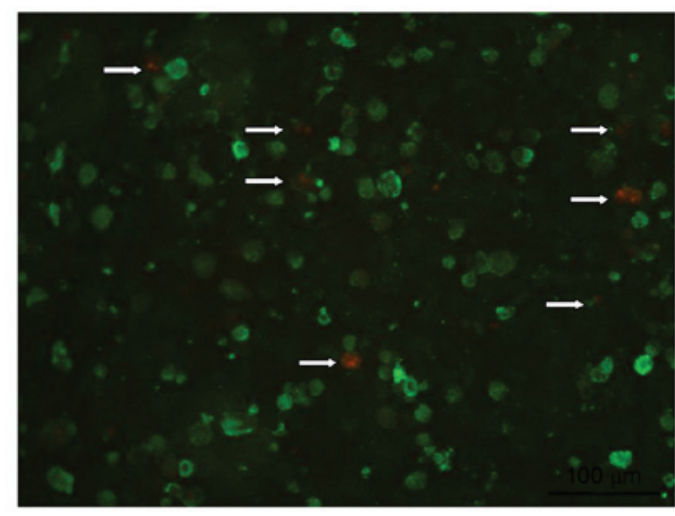

C

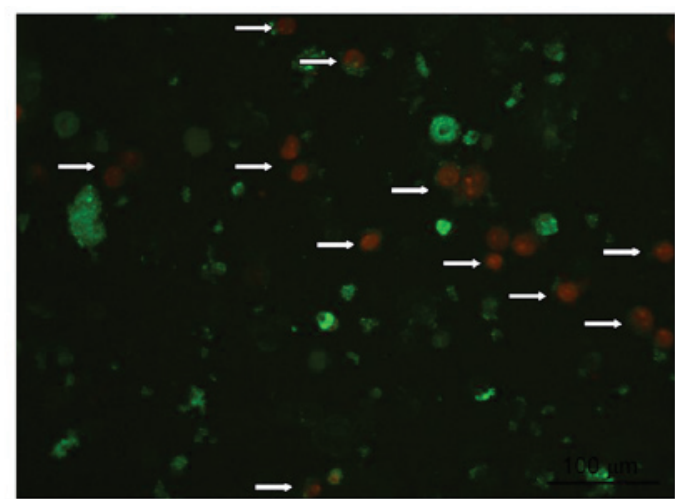

Figure 2. Apoptosis was induced in HeLa229 cells following treatment with berberine hydrochloride for $48 \mathrm{~h}$. (A) Untreated control, (B) $26.896 \mu \mathrm{mol} / 1$ berberine hydrochloride-treated and (C) $107.584 \mu \mathrm{mol} / 1$ berberine hydrochloride-treated cells were stained with Annexin V-fluorescein isothiocyanate (green) and propidium iodide (red) to detect early and late apoptotic cells. The cell membranes of early and late apoptotic cells were stained green; whereas late apoptotic cells had additionally red-stained nuclei accompanied by condensed chromatin and apoptotic bodies. Magnification, x200. Arrows indicate late apoptotic cells or condensed chromatin or apoptotic bodies.

group at $48 \mathrm{~h}$ to $45.37 \%$ in the $107.584 \mu \mathrm{mol} / \mathrm{l}$ treatment group for $72 \mathrm{~h}$. Significant differences were observed in the proportions of intact cells (non-apoptotic live cells) at 24, 48 and $72 \mathrm{~h}$ between the three groups (all $\mathrm{P}<0.001$ ). In addition, compared with control groups, significant differences were detected in the proportions of early and late apoptotic cells at $72 \mathrm{~h}$ [all $\mathrm{P}<0.001$, except early apoptotic cells of the $42.93 \mu \mathrm{mol} / 1$ treatment group $(\mathrm{P}=0.007)]$, and in the percentage of total apoptotic cells at $24(42.93 \mu \mathrm{mol} / 1, \mathrm{P}=0.001 ; 107.584 \mu \mathrm{mol} / 1, \mathrm{P}<0.001)$, 48 and $72 \mathrm{~h}($ all $\mathrm{P}<0.001)$. Compared with the $42.93 \mu \mathrm{mol} / \mathrm{l}$ berberine hydrochloride treatment group, the $107.584 \mu \mathrm{mol} / 1$ berberine hydrochloride treatment group revealed significant 
A
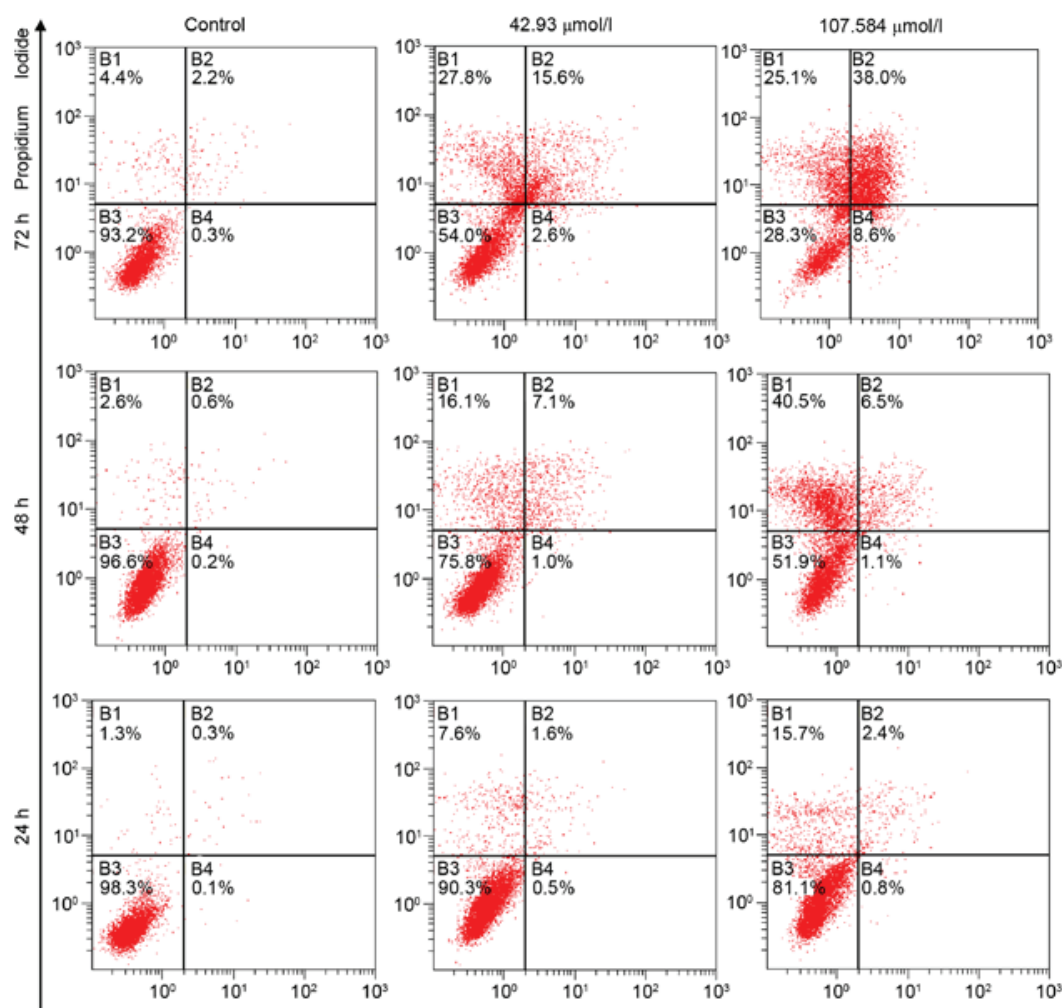

Annexin V-FITC
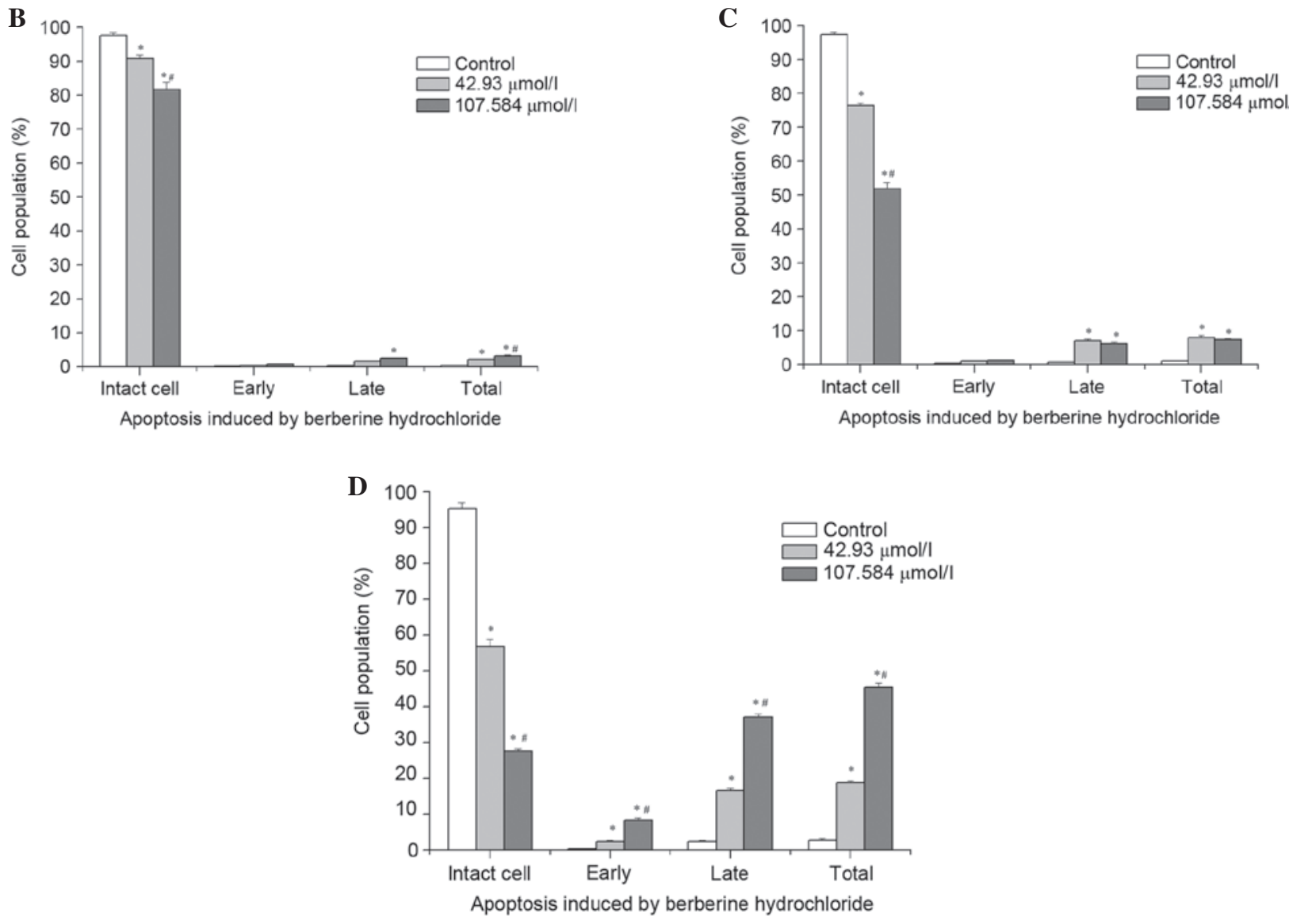

Figure 3. Apoptosis of HeLa229 cells treated with 42.93 or $107.584 \mu \mathrm{mol} / 1$ berberine hydrochloride for 24,48 or 72 h. (A) Flow cytometry was performed on cells stained with Annexin V-FITC and PI. The intact (live) cells are negative for Annexin V-FITC and PI (lower left quadrant). Early apoptotic cells are defined as Annexin V-FITC-positive and PI-negative (lower right quadrant) and late apoptotic cells are defined as Annexin V-FITC-positive and PI-positive (upper right quadrant). The proportion of intact, and early, late, and total apoptotic cells was determined at (B) 24, (C) 48 and (D) $72 \mathrm{~h}$. Berberine hydrochloride induced apoptosis of HeLa229 cells in a dose- and time-dependent manner. Data are presented as the mean \pm standard deviation of three determinations. ${ }^{\text {} P} \mathrm{P}<0.05$ vs. control; ${ }^{\#} \mathrm{P}<0.05$ vs. $42.93 \mu \mathrm{mol} / \mathrm{l}$ berberine hydrochloride. FITC, fluorescein isothiocyanate; $\mathrm{PI}$, propidium iodide. 
differences $(\mathrm{P}<0.001)$ in the percentage of intact cells at all time points and early and late apoptotic cells at $72 \mathrm{~h}$, and in the percentage of total apoptotic cells at $24 \mathrm{~h}(\mathrm{P}=0.014)$ and $72 \mathrm{~h}(\mathrm{P}<0.001)$. These results suggest that berberine hydrochloride induced apoptosis of HeLa229 cells in a dose- and time-dependent manner.

mRNA expression levels in berberine hydrochloride-treated cells. p53, Bcl-2 and cox-2 mRNA expression levels in HeLa229 cells were assessed by RT-qPCR, following treatment with $21.465,42.93$ or $107.584 \mu \mathrm{mol} / 1$ berberine hydrochloride for $48 \mathrm{~h}$ (Fig. 4). Berberine hydrochloride upregulated mRNA expression levels of p53, whereas mRNA expression levels of Bcl-2 and cox-2 were downregulated in a dose-dependent manner. mRNA expression levels of p53 increased from 1.287- to 2.57-fold relative to control, whereas mRNA expression levels of cox-2 decreased from 0.856-to 0.545-fold, and Bcl-2 decreased from 0.962 - to 0.775 -fold. Significant differences were observed in p53 mRNA expression levels between treated $(21.465 \mu \mathrm{mol} / \mathrm{l}$, $\mathrm{P}=0.025 ; 42.93 \mu \mathrm{mol} / 1, \mathrm{P}<0.001 ; 107.584 \mu \mathrm{mol} / 1, \mathrm{P}<0.001)$ and untreated control cells, and in cox-2 mRNA expression levels between cells treated with $42.93(\mathrm{P}=0.039)$ or 107.584 $(\mathrm{P}=0.002) \mu \mathrm{mol} / 1$ berberine hydrochloride and control cells.

\section{Discussion}

Berberine is a naturally-occurring isoquinoline alkaloid, which exerts antitumor effects on numerous cancer types (5,30-38) and is non-toxic to normal cells (22). However, the effects of berberine on the HeLa229 human cervical carcinoma cell line remain unclear.

The results of the present study suggested that treatment with berberine hydrochloride for $72 \mathrm{~h}$ significantly decreased the viability of HeLa229 cells. Annexin V and PI staining demonstrated that berberine hydrochloride treatment resulted in apoptosis of HeLa229 cells. Apoptosis is tightly regulated by anti- and proapoptotic effector molecules (39) and is caused by the activation of caspases. Two separate pathways (extrinsic and intrinsic) of caspase activation have been described (40). p53 is a critical regulator of apoptosis (41), initiating the intrinsic pathway via the transcriptional activation of Bcl-2 family members (42). The Bcl-2 family consists of three major groups, which differ in regions of $\mathrm{Bcl}-2$ homology ( $\mathrm{BH}$ domains) and function: Multidomain anti-apoptotic (including Bcl-2), multidomain proapoptotic and $\mathrm{BH} 3$-only proapoptotic (43). Berberine hydrochloride may upregulate the expression levels of p53, triggering the intrinsic pathway of apoptosis via downregulation of Bcl-2 expression levels. This would result in release of cytochrome $c$ in the mitochondrial membrane and activation of caspase-9, resulting in apoptosis (44). Cox-2 is a target for anticancer therapy (45), which is involved in the extrinsic pathway. Its expression increases as cells become cancerous (46), and it is associated with the stimulation of angiogenesis, and tumor growth, invasion and metastasis (47-49). In the present study, treatment with berberine hydrochloride increased the expression of p53 and decreased the expression of Bcl-2 and cox-2, in a dose-dependent manner. These results are consistent with a previous study, which demonstrated that berberine induced apoptosis via a significant decrease in the Bcl-2/Bax ratio, and the upregulation of Fas, Fas ligand, tumor necrosis factor

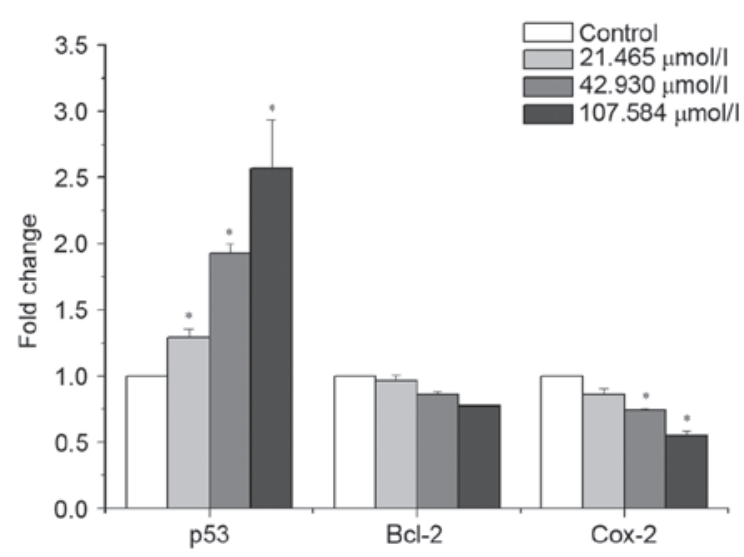

Figure 4. Berberine hydrochloride alters mRNA expression levels in HeLa229 cells. Cells were stimulated with 21.465 , 42.93 or $107.584 \mu \mathrm{mol} / 1$ berberine hydrochloride for $48 \mathrm{~h}$, and RNA was extracted for reverse transcription-quantitative polymerase chain reaction analysis of p53, Bcl-2 and cox-2. Berberine hydrochloride upregulated mRNA expression levels of p53, whereas mRNA expression levels of Bcl-2 and cox-2 were downregulated in a dose-dependent manner. Each sample was run in triplicate, and the relative amount of mRNA was normalized to $\beta$-actin. Fold-changes compared with control are presented. Data are presented as the mean \pm standard deviation of three determinations. " $\mathrm{P}<0.05$ vs. control. Bcl-2, B-cell lymphoma 2; cox-2, cyclooxygenase- 2 .

(TNF)- $\alpha$, TNF receptor-associated factor 1 and p53 in HeLa cells (14).

In conclusion, the results of the present study suggested that berberine hydrochloride may exhibit significant cytotoxicity against HeLa229 cells. At the lowest concentration assessed (3.362 $\mu \mathrm{mol} / \mathrm{l})$, the inhibition of HeLa229 cells by berberine hydrochloride was $<1 \%(0.44 \%)$; however, inhibition increased to $>96 \%(96.39 \%)$ at the maximum concentration examined (215.168 $\mu \mathrm{mol} / \mathrm{l})$. Berberine hydrochloride induced typical characteristics of apoptosis in HeLa229 cells, including nuclear condensation, nuclear fragmentation and the formation of apoptotic bodies. In addition, 42.93 and $107.584 \mu \mathrm{mol} / 1$ berberine hydrochloride induced apoptosis in a time-dependent manner. Berberine hydrochloride induced apoptosis in HeLa229 cells via the activation of the extrinsic and intrinsic pathways, involving the upregulation of p53 mRNA expression levels and the downregulation of Bcl-2 and cox-2 mRNA expression levels. Therefore, berberine appears to be a potential therapeutic agent for the treatment of cervical cancer.

\section{Acknowledgements}

The present study was supported by a grant from the Science and Technology Research Project of Hubei Provincial Department of Education (grant no. Q20092504) and a grant from the Discipline Groups Construction of Food New-type Industrialization of Hubei University of Arts and Science (grant no. XKQ08321).

\section{References}

1. Xie J, Xu Y, Huang X, Chen Y, Fu J, Xi M and Wang L: Berberine-induced apoptosis in human breast cancer cells is mediated by reactive oxygen species generation and mitochondrial-related apoptotic pathway. Tumour Biol 36: 1279-1288, 2015. 
2. Parkin DM: The global health burden of infection-associated cancers in the year 2002. Int J Cancer 118: 3030-3044, 2006.

3. Engel N, Oppermann C, Falodun A and Kragl U: Proliferative effects of five traditional Nigerian medicinal plant extracts on human breast and bone cancer cell lines. J Ethnopharmacol 137: 1003-1010, 2011

4. Sun Y, Xun K, Wang Y and Chen X: A systematic review of the anticancer properties of berberine, a natural product from Chinese herbs. Anticancer Drugs 20: 757-769, 2009.

5. Li X, Zhao SJ, Shi HL, Qiu SP, Xie JQ, Wu H, Zhang BB, Wang ZT, Yuan JY and Wu XJ: Berberine hydrochloride IL-8 dependently inhibits invasion and IL-8-independently promotes cell apoptosis in MDA-MB-231 cells. Oncol Rep 32: 2777-2788, 2014.

6. Xi S, Chuang K, Fang K, Lee Y, Chung J and Chuang Y: Effect of berberine on activity and mRNA expression of $\mathrm{N}$-acetyltransferase in human lung cancer cell line A549. J Tradit Chin Med 34: 302-308, 2014

7. Guamán Ortiz LM, Tillhon M, Parks M, Dutto I, Prosperi E, Savio M, Arcamone AG, Buzzetti F, Lombardi P and Scovassi AI Multiple effects of berberine derivatives on colon cancer cells Biomed Res Int 2014: 924585, 2014.

8. Wu HL, Chuang TY, Al-Hendy A, Diamond MP, Azziz R and Chen YH: Berberine inhibits the proliferation of human uterine leiomyoma cells. Fertil Steril 103: 1098-1106, 2015.

9. Qing Y, Hu H, Liu Y, Feng T, Meng W, Jiang L, Sun Y and Yao Y: Berberine induces apoptosis in human multiple myeloma cell line U266 through hypomethylation of p 53 promoter. Cell Biol Int 38: 563-570, 2014

10. Zhu Y, Ma N, Li HX, Tian L, Ba YF and Hao B: Berberine induces apoptosis and DNA damage in MG-63 human osteosarcoma cells. Mol Med Rep 10: 1734-1738, 2014.

11. Zhang Q, Zhang C, Yang X, Yang B, Wang J, Kang Y, Wang Z, Li D, Huang G, Ma Z, et al: Berberine inhibits the expression of hypoxia induction factor-1alpha and increases the radiosensitivity of prostate cancer. Diagn Pathol 9: 98, 2014.

12. Zhang LY, Wu YL, Gao XH and Guo F: Mitochondrial protein cyclophilin-D-mediated programmed necrosis attributes to berberine-induced cytotoxicity in cultured prostate cancer cells. Biochem Biophys Res Commun 450: 697-703, 2014.

13. Chu SC, Yu CC, Hsu LS, Chen KS, Su MY and Chen PN: Berberine reverses epithelial-to-mesenchymal transition and inhibits metastasis and tumor-induced angiogenesis in human cervical cancer cells. Mol Pharmacol 86: 609-623, 2014.

14. Lu B, Hu M, Liu K and Peng J: Cytotoxicity of berberine on human cervical carcinoma HeLa cells through mitochondria, death receptor and MAPK pathways, and in-silico drug-target prediction. Toxicol In Vitro 24: 1482-1490, 2010.

15. Li CH, Wu DF, Ding H, Zhao Y, Zhou KY and Xu DF: Berberine hydrochloride impact on physiological processes and modulation of twist levels in nasopharyngeal carcinoma CNE-1 cells. Asian Pac J Cancer Prev 15: 1851-1857, 2014.

16. Zhang C, Yang X, Zhang Q, Yang B, Xu L, Qin Q, Zhu H, Liu J, Cai J, Tao G, et al: Berberine radiosensitizes human nasopharyngeal carcinoma by suppressing hypoxia-inducible factor-1 $\alpha$ expression. Acta Otolaryngol 134: 185-192, 2014.

17. Wang N, Zhu M, Wang X, Tan HY, Tsao SW and Feng Y: Berberine-induced tumor suppressor p53 up-regulation gets involved in the regulatory network of MIR-23a in hepatocellular carcinoma. Biochim Biophys Acta 1839: 849-857, 2014.

18. Wang L, Wei D, Han X, Zhang W, Fan C, Zhang J, Mo C, Yang M, Li J, Wang Z, et al: The combinational effect of vincristine and berberine on growth inhibition and apoptosis induction in hepatoma cells. J Cell Biochem 115: 721-730, 2014.

19. Guo N, Yan A, Gao X, Chen Y, He X, Hu Z, Mi M, Tang X and Gou X: Berberine sensitizes rapamycin-mediated human hepatoma cell death in vitro. Mol Med Rep 10: 3132-3138, 2014.

20. Zhang XZ, Wang L, Liu DW, Tang GY and Zhang HY: Synergistic inhibitory effect of berberine and d-limonene on human gastric carcinoma cell line MGC803. J Med Food 17: 955-962, 2014

21. Mittal A, Tabasum S and Singh RP: Berberine in combination with doxorubicin suppresses growth of murine melanoma B16F10 cells in culture and xenograft. Phytomedicine 21: 340-347, 2014.

22. Mahata S, Bharti AC, Shukla S, Tyagi A, Husain SA and Das BC: Berberine modulates AP-1 activity to suppress HPV transcription and downstream signaling to induce growth arrest and apoptosis in cervical cancer cells. Mol Cancer 10: 39, 2011.

23. Lin JP, Yang JS, Chang NW, Chiu TH, Su CC, Lu KW, Ho YT, Yeh CC, Mei-Dueyang, Lin HJ and Chung JG: GADD153 mediates berberine-induced apoptosis in human cervical cancer Ca ski cells. Anticancer Res 27: 3379-3386, 2007.
24. Abu Bakar MF, Mohamad M, Rahmat A, Burr SA and Fry JR Cytotoxicity, cell cycle arrest, and apoptosis in breast cancer cell lines exposed to an extract of the seed kernel of Mangifera pajang (bambangan). Food Chem Toxicol 48: 1688-1697, 2010.

25. Tian Z, An N, Zhou B, Xiao P, Kohane IS and Wu E: Cytotoxic diarylheptanoid induces cell cycle arrest and apoptosis via increasing ATF3 and stabilizing p53 in SH-SY5Y cells. Cancer Chemother Pharmacol 63: 1131-1139, 2009.

26. Itoh M, Murata T, Suzuki T, Shindoh M, Nakajima K, Imai K and Yoshida K: Requirement of STAT3 activation for maximal collagenase-1 (MMP-1) induction by epidermal growth factor and malignant characteristics in T24 bladder cancer cells. Oncogene 25: 1195-1204, 2006.

27. Jiang N, Zhou LQ and Zhang XY: Downregulation of the nucleosome-binding protein 1 (NSBP1) gene can inhibit the in vitro and in vivo proliferation of prostate cancer cells. Asian J Androl 12: 709-717, 2010

28. Zhou A, Scoggin S, Gaynor RB and Williams NS: Identification of NF-kappa B-regulated genes induced by TNFalpha utilizing expression profiling and RNA interference. Oncogene 22: 2054-2064, 2003.

29. Lapillonne H, Konopleva M, Tsao T, Gold D, McQueen T, Sutherland RL, Madden T and Andreeff M: Activation of peroxisome proliferator-activated receptor gamma by a novel synthetic triterpenoid 2-cyano-3, 12-dioxooleana-1,9-dien-28-oic acid induces growth arrest and apoptosis in breast cancer cells. Cancer Res 63: 5926-5939, 2003.

30. Chidambara Murthy KN, Jayaprakasha GK and Patil BS: The natural alkaloid berberine targets multiple pathways to induce cell death in cultured human colon cancer cells. Eur J Pharmacol 688: 14-21, 2012.

31. Hur JM, Hyun MS, Lim SY, Lee WY and Kim D: The combination of berberine and irradiation enhances anti-cancer effects via activation of p38 MAPK pathway and ROS generation in human hepatoma cells. J Cell Biochem 107: 955-964, 2009.

32. Kim JB, Yu JH, Ko E, Lee KW, Song AK, Park SY, Shin I, Han W and Noh DY: The alkaloid Berberine inhibits the growth of Anoikis-resistant MCF-7 and MDA-MB-231 breast cancer cell lines by inducing cell cycle arrest. Phytomedicine 17: 436-440, 2010.

33. Wang J, Liu Q and Yang Q: Radiosensitization effects of berberine on human breast cancer cells. Int J Mol Med 30: 1166-1172, 2012

34. Chou HC, Lu YC, Cheng CS, Chen YW, Lyu PC, Lin CW, Timms JF and Chan HL: Proteomic and redox-proteomic analysis of berberine-induced cytotoxicity in breast cancer cells. J Proteomics 75: 3158-3176, 2012.

35. Zheng F, Tang Q, Wu J, Zhao S, Liang Z, Li L, Wu W and Hann S: p38 a MAPK-mediated induction and interaction of FOXO3a and p53 contribute to the inhibited-growth and induced-apoptosis of human lung adenocarcinoma cells by berberine. J Exp Clin Cancer Res 33: 36, 2014

36. Ma X, Zhou J, Zhang CX, Li XY, Li N, Ju RJ, Shi JF, Sun MG, Zhao WY, Mu LM, et al: Modulation of drug-resistant membrane and apoptosis proteins of breast cancer stem cells by targeting berberine liposomes. Biomaterials 34: 4452-4465, 2013.

37. Qi HW, Xin LY, Xu X, Ji XX and Fan LH: Epithelial-tomesenchymal transition markers to predict response of Berberine in suppressing lung cancer invasion and metastasis. J Transl Med 12: 22, 2014

38. Scordino A, Campisi A, Grasso R, Bonfanti R, Gulino M, Iauk L, Parenti R and Musumeci F: Delayed luminescence to monitor programmed cell death induced by berberine on thyroid cancer cells. J Biomed Opt 19: 117005, 2014

39. Weyhenmeyer B, Murphy AC, Prehn JH and Murphy BM: Targeting the anti-apoptotic bcl-2 family members for the treatment of cancer. Exp Oncol 34: 192-199, 2012.

40. Green DR: Apoptotic pathways: Paper wraps stone blunts scissors. Cell 102: 1-4, 2000

41. Žegura B, Gajski G, Štraser A and Garaj-Vrhovac V: Cylindrospermopsin induced DNA damage and alteration in the expression of genes involved in the response to DNA damage, apoptosis and oxidative stress. Toxicon 58: 471-479, 2011.

42. Vogelstein B, Lane D and Levine AJ: Surfing the p53 network. Nature 408: 307-310, 2000

43. Certo M, Del Gaizo Moore V, Nishino M, Wei G, Korsmeyer S, Armstrong SA and Letai A: Mitochondria primed by death signals determine cellular addiction to antiapoptotic BCL-2 family members. Cancer Cell 9: 351-365, 2006. 
44. Kim R, Tanabe K, Uchida Y, Emi M, Inoue H and Toge T: Current status of the molecular mechanisms of anticancer drug-induced apoptosis. The contribution of molecular-level analysis to cancer chemotherapy. Cancer Chemother Pharmacol 50: 343-352, 2002.

45. Zhang C, Yan W, Li B, Xu B, Gong Y, Chu F, Zhang Y, Yao Q, Wang $\mathrm{P}$ and Lei $\mathrm{H}$ : A New Ligustrazine Derivative-Selective Cytotoxicity by Suppression of NF-kB/p65 and COX-2 expression on human hepatoma cells. Part 3. Int J Mol Sci 16: 16401-16413, 2015

46. Breinig M, Schirmacher P and Kern MA: Cyclooxygenase-2 (COX-2)-a therapeutic target in liver cancer? Curr Pharm Des 13: $3305-3315,2007$
47. Tang TC, Poon RT, Lau CP, Xie D and Fan ST: Tumor cyclooxygenase-2 levels correlate with tumor invasiveness in human hepatocellular carcinoma. World J Gastroenterol 11: 1896-1902, 2005.

48. Zhong B, Cai X, Chennamaneni S, Yi X, Liu L, Pink JJ, Dowlati A, Xu Y, Zhou A and Su B: From COX-2 inhibitor nimesulide to potent anti-cancer agent: Synthesis, in vitro, in vivo, and pharmacokinetic evaluation. Eur J Med Chem 47: 432-444, 2012

49. Mazhar D, Gillmore R and Waxman J: COX and cancer. QJM 98: 711-718, 2005. 